\title{
Dolmuşun (Uzun) Öyküsü: Basımının Kırkıncı Yılında İlhan Tekeli ve Tarık Okyay'ın Benzersiz Çalışması Üzerine
}

\author{
* \\ Besim Can Zirh ${ }^{1}$ \\ ORCID: 0000-0003-3506-6096
}

Öz

Bu yazı İlhan Tekeli ve Tarık Okyay'ın 1980 yılında basılan "Dolmuşun Öyküsü" kitabını hatırlamak üzere İlhan Tekeli özel sayısı için kaleme alınmış bir kitap değerlendirmesidir. "Dolmuşun Öyküsü" kitabı İlhan Tekeli ve Tarık Okyay'ın Yiğit Gülöksüz ile birlikte gerçekleştirdikleri ve 1976 yılında "Gecekondulu, Dolmuşlu, İşportalı Şehir" başlığında yayımlanan bir çalışmadan ilham almakta ve ODTÜ Planlama Bölümü öğrencilerinin 1974 yılındaki "Yaz Stajı" kapsamında karma yöntemle gerçekleştirilen bir dizi araştırmaya dayanmaktadır. Çalışmanın dolmuş konusunda bugün halen geçerli olan bir dizi ön kabulü bilimsel bir yaklaşımla tartışmaya açması ve dolmuş olgusunu çeper ülke kentleşmesi bağlamında inceliyor olmasıyla kentleşme çalışmalarında oldukça özgün bir yere sahiptir. Basımından 40 yıl sonra dahi Türkiye'nin kente dair ulaşım başta olmak üzere birçok temel sorununun nasıl incelenebileceğine dair ışık tutan çalışma dolmuşa dair dönemin popüler kültüründen malzemeleri de içermektedir. Tekeli ve Okyay'ın bu özgün araştırma sonucunda dolmuşun geleceği hakkında geliştirdikleri varsayımların ne ölçüde gerçekleşmiş olduğunu yeni çalışmalar ışı̆̆ında tartışmak gerekir ve böyle bir çaba yazının kapsamı dışında kalır.

Anahtar Kelimeler: kentleşme, ulaşım, dolmuş, Ankara, toplumsal araştırma.

${ }^{1}$ Dr. Öğretim Üyesi, ODTÜ, E-mail: besimcan@metu.edu.tr

idealkent @ Kent Araştırmaları Dergisi (Journal of Urban Studies)

http://idealkentdergisi.com

Geliş Tarihi Received Date: 16.02.2020 Kabul Tarihi Accepted Date:25.04.2020 


\title{
The (Long) Story of Dolmus/Jitney: Reading İlhan Tekeli and Tarik Okyay's Unprecedented Work on the Fortieth Anniversary of Its Publication
}

\author{
* \\ Besim Can Zirh ${ }^{2}$ \\ ORCID: 0000-0003-3506-6096
}

\begin{abstract}
This essay was written to remind Ilhan Tekeli and Tarık Okyay's work Dolmuşun Öyküsü (The Story of Dolmuş) published in 1980. This work was inspired by another research conducted by İlhan Tekeli and Tarık Okyay with Yiğit Gülöksüz in 1976. As they realized that the phenomenon of dolmuş was overlooked in newly developing body of research on urbanization in Turkey, Tekeli and Okyay decided to conduct a follow-up research with the students of Middle East Technical University, Urban Planning Department as their summer internship. This collective research was designed on mixed-methodology approached and aims to critically analyze takenfor-granted assumptions about dolmuş as a particular system of intracity transportation. Even on its fortieth anniversary of publication. The Story of Dolmuş continues to be relevant in the context of contemporary urbanization in Turkey. It would be necessity that their assumptions about the future of dolmuş need to be examined in the light of new research to see whether if they were right or not, however this cannot be in the scope of this essay.
\end{abstract}

Keywords: Urbanization, transportation, dolmuş/jitney, Ankara, social research.

${ }^{2}$ Assist Prof. Dr., METU, E-mail: besimcan@metu.edu.tr

idealkent @ Kent Araştırmaları Dergisi (Journal of Urban Studies)

http://idealkentdergisi.com

Geliş Tarihi Received Date: 16.02.2020 Kabul Tarihi Accepted Date: 25.04.2020 


\section{Giriş: Dolmuşun Unutulmuş Öyküsü}

2019 yılının son aylarında ODTÜ öğrencileri tıpkı Hacettepe'deki arkadaşları gibi kampüslerine kamusal ve düzenli ulaşım için bir kampanya başlattı ve seslerini duyurabilmek için taleplerini \#ulasamiyoruzhocam etiketiyle sosyal medyaya taşıdı. Herkese açık olarak yapılan paylaşımlardan birkaçını 2020'lerde Türkiye'nin, 60 yıllık tarihe sahip en iyi üniversitelerinden birine ulaşım konusundaki durumu çerçevelemek için aktarmak isterim.

- "Size bir fikra anlatayım, bi keresinde evden okula gitmek için önce otobüsle batıkente, sonra metroyla akköprüye, sonra otobüsle akm'ye, sonra metroyla aktarmalı şekilde odtü metroya, sonra da ringle derse gitmiştim" (Keçiören Metrosu'nda çalışma olduğundan). (Ilhami Aranzubia)

- "Daha komik bir fikra geliyor, Oturduğum yer bahçelievler (milli kütüphane değil) Arabayla ODTÜ'ye ulaşım max 15 dakika. Metro ile 45 dakika:'))) 4 yıldır kesintisiz her gün bu fikrayı yaşıyorum" (Arkonem değil Arco-İis).

- "Kırıkkalde oturan bi arkadaşım okuldan eve giderken benden önce dönüyor" (ah bu ben)

- "Her gün Kırıkkale'de okusam şimdiye evde olmuştum demekten ayrı, otobüslerde harap olmaktan ayrı yoruldum. 3 saat çok fazla. Semt servisleri istiyoruz!" (Nomorealeyna)

Bu kampanyayla ODTÜ'de okumaya başladığım 90'ların ikinci yarısını, bir öğrenci olarak barınma ve ulaşım konusunda yaşadığım güçlükleri anımsadım. Bir yanıyla İstanbul'dan Ankara'ya taşınmış olmak, yeni bir şehir deneyimi; diğer yanıyla üniversite hayatına uyum birçoğumuz gibi benim için de dönüştürücü bir deneyimdi. Bu yıllara dair çok açık anımsadığım bir diğer şey ise ODTÜ'ye başladıktan sonra aldığım ilk kitaptır. Bookstore'un raflarında ilginç ismi ve özgün kapağıyla (Görsel 1) dikkatimi çeken kitabı elime aldığımda bir kente, bir topluma dolmuşun penceresinden bakma fikri beni çok etkilemişti. Aradan geçen yıllara karşın ulaşımın Türkiye'de öğrenci deneyiminin halen en belirleyici meselelerinden biri olmasıyla Dolmuşun Öyküsü'yle karşılaşmamı anımsadım.

Bu yazı İlhan Tekeli ve Tarık Okyay'ın 1980 yılında basılan “Dolmuşun Öyküsü" kitabını hatırlamak üzere İlhan Tekeli özel sayısı için kaleme alınmış bir kitap değerlendirmesidir. Basımından 40 yıl sonra dahi Ankara başta olmak üzere Türkiye'nin birçok kentinde ulaşımın başat aktörü dolmuşları 
anlamamız açısından güncelliğini koruyan bu çalışma dolmuş konusunda bugün halen geçerli olan bir dizi ön kabulü bilimsel bir yaklaşımla tartışmaya açması ve dolmuş olgusunu çeper ülke kentleşmesi bağlamında inceliyor olmasıyla kentleşme çalışmalarında özgün bir yere sahip. Diğer yandan yazının amacının bu çalışmadaki argümanların geçerliliğini tartışmak ya da güncellemek olmadığını açıkça not etmek isterim.

İlhan Tekeli ve Tarık Okyay'ın hazırladıkları çalışma iki nedenle oldukça özgün ve önemli. İlki memlekete dair bir durum olarak bilimsel çalışma yapmanın dönemsel güçlüklerine işaret ediyor:

- “Dolmuş olgusunu inceleme konusunda yazarların ilgisini yoğunlaştıran gelişmeler yanı sıra, bu araştırmanın yapılmasını olanaklı kılan bir fırsat ortaya çıkmıştır. Son yılların çalkantılı eğitim ortamı içinde ODTÜ Şehir Planlama Bölümü öğrencilerinin 1974 yılı yaz stajı, başka bir olanak kalmadığından öğrencilerin de isteğiyle Ankara'da 'dolmuş' olgusunun araştırılmasına yöneldi. Bu çalışmada yararlandığımız alan araştırması sıkıntılı bir eğitim ortamının zorunluluklarından doğmuş oldu. Çalışmamız böyle sıkıntılı bir ortamda özveriyle çalışan ODTÜ Planlama Bölümü öğrencilerine çok şey borçludur" (s. ii).

İkincisi ise konunun neden gözden kaçmış olduğuna dair bir saptama:

- "Bir toplumsal olgunun araştırılmamış olması, bu olgunun bir sorun niteliğinde görülmediğinin bir kanıtı olarak yorumlanabilir. Toplumsal araştırmaların gecekondu üstüne yoğunlaşması, bir rastlantı değildi. Doğuşundan beri bir orta sınıf üyesi olan plancilar, yöneticiler ve toplumbilimcilerce gecekonduya bir sorun olarak bakılmasındandı" (s. ii).

İlhan Tekeli ve Tarık Okyay, Yiğit Gülöksüz'ün de katıldığı ve 1976 y1lında Gecekondulu, Dolmuşlu, İşportalı Şehir başlıklı bir kitap olarak basılan çalışmaları sürecinde dolmuş üzerine bir çalışma olmadığını fark ederler. Onlara göre bu durum araştırmaciların sınıfsal konumundan kaynaklanan yöntemsel bir körlügün yansımasıdır. 20 temel başlık altında giriştikleri kapsamlı bir incelemedir. Söz gelimi: “Özel Araba Sahipliği ve Otomobil Üretimi Aç1sından Şehirsel Ulaşım Sorunu”, "Şehirlerimizde Çıkar Grupları Açısından Plansızlık", "Şehir Halkının Beslenmesinde Bir Dağıtım Kontrol Merkezi: Toptanc Halleri" ve "Şehirlerimizde Yeni Bir Büyüme Biçimi: Toplu Konut." Bu 20 başlıktan altıncısı ise "Dolmuşlar ve Dolmuşçular" üzerinedir.

Dolayısıyla Tekeli ve Okyay bilim insanları olarak yaptıkları bir çalışmada Türkiye kent çalışmaları açısından bir noksanlık tespit etmişler, bu meseleyi 
öğrencileriyle birlikte ortaklaşarak bir araştırma konusu olarak çalışmışlardır. Çalışma oldukça ilginç karma bir yönteme dayanmaktadır. Bir yandan ulaşım gibi konulardan sorumlu kamu aklının yaptığı çalışmaları temel bir veri kaynağı olarak kullanıyorlar. Diğer yandan toplumun dolmuş konusunda nasıl bir algısı ve ön-kabulleri olduğunu anlamak üzere köşe yazıları ve daha da değerlisi yine kültürel bir öge olarak karikatürlere bakıyorlar (Görsel 7). Araştırmanın diğer kısmı ise dolmuş yolcuları ve dolmuşçularla gerçekleştirilen soru kâğıdına dayalı görüşmelere ve örgüt üye ve yöneticileriyle yapılan mülakatlara ve katılımc gözleme dayanıyor. Bu yöntemlere ilişkin notları ilgili kısımları tartışırken belirteceğim.

\section{Birinci Bölüm: Dolmuş Nedir?}

Tekeli ve Okyay'a göre "gecekondu" dendiğinde alt-sınıf bir konut tipi anlaşlacakken "dolmuş" konusunda böyle bir anlam-birliği olduğunu söylemek mümkün değildir. Bu nedenle ilk bölüm “Dolmuş nedir?” başlığı altında bu özgün taşıma sisteminin bir araştırma konusu olarak tanımını yapmaya odaklanır. Bu tanım, çalışmanın kalanı açısından temel bir referans oluşturma çabasıdır ve "Yolcuların tek tek bindiği ve dolunca yola çıkan taşıttır" gibi 10 temel önermeyle genel bir çerçeve çizilir.

Sonrasında bir hizmet olarak ulaşımın nasıl örgütlendiği, kimin kimden nasıl bir hizmeti hangi usullerle aldığı gibi sorular çerçevesinde tanımlanır. Sözgelimi "ancak dolunca yola çıkması" dolmuşu belirli bir tarifeye göre sunulan ulaşım hizmetlerinden farklılaştırmaktadır. Bu hizmetten yararlanan kişiler olarak yolcular ise öncesinde birbirini tanımaya gerek duymayan fakat belirli bir zamanda bu hizmeti almak üzere bir araya gelmiş ve hizmet bedelini aralarında paylaşan bir müşteri kümesidir. Buna karşın bu hizmeti sunan kişiler olarak dolmuşçular genelde aile ya da akrabalık ilişkilerine dayalı bir sermaye (dolmuş) ve ucuz (sigortasız, güvencesiz ve uzun saatlere dayalı) emek kaynağına erişimi olan küçük işletmeci olarak tekelleşme eğilimine sahip olması pek mümkün olmayan kendi işinin işçisi "marjinal" kesim üyeleridir. 1960'ların sonunda bir standartlaşma gelene kadar steyşın taksi ya da minibüs gibi farklı araç tiplerinin kullanılabildiği bir ulaşım hizmetidir.

Toplumsal bilimlerde odaklanılan bu gibi olguları çalışabilir hale getirmek (operationalization) her araştırmanın ilk adımıdır. Tekeli ve Okyay öncelikle on temel önerme kapsamında bir "dolmuş kümesi" oluştururlar (s. 15). Bu tanımlama aşamasının tamamlayıcı bir parçası olarak çizilen kümenin barındırdığı farklılıkları da tartışırlar. Bu kapsamda dolmuş genel kümesi 
içinde (a) hizmet sunulan alan (kent-içi ya da kent hinterlandı), (b) kısmen buna dayalı olarak yolcu taşıma kapasitesi (kent-içi alanlarda altı ya da yedi kişilik taksi/steyşın dolmuşçuluk, kent hinterlandına doğru 11 kişilik minibüsçülük) ve (c) yolculuk amacına göre (özel amaçli taksi dolmuş, ilkokul öğrencilerine yönelik taksi dolmuş ve hatlı genel dolmuşçuluk) farklı biçimler olduğu unutulmamalıdır. Tekeli ve Okyay çalışmalarında bu farkları da göz önünde bulundurarak dolmuş kümesini bir bütün olarak çalışacaklarını söyleyerek ilk bölümü tamamlyor.

\section{Bölüm 2: Dolmuşun Varlığı Nelere Bağlıdır?}

İkinci bölümün odak sorusu “Dolmuşun varlığı nelere bağlıdır?" olarak tanımlanıyor. Bu bölümde Tekeli ve Okyay dolmuşu Türkiye gibi çeper ülkelerde yaşanan hızlı kentleşmeye bağlı olarak oluşan yolculuk taleplerinin kamusal ulaşım sistemleriyle karşılanamamasının bir sonucu olarak tartışıyor (s. 23-24). Buna karşın kamunun talebi tümüyle karşılayabildiğinde dolmuşa olan ihtiyacın ve dolayısıyla dolmuş sisteminin ortadan kalkacağına dair genel kabulün ise mevcut verilerle sınanamayacağını belirttikten sonra gerçekte bu varsayımın temel önermeleri nedeniyle tartışmaya açık olduğunu not ederken "tarihi örneklerden yararlanmak" (s. 24) gereğine işaret ediyorlar. Onlara göre bu yaygin ön kabul; (a) dolmuş ve kamu sistemlerince sunulan ulaşım hizmetlerinin aynı nitelikte olması, (b) kamu taşıma sistemlerinin dolmuştan daha düşük maliyetli olması ve (c) "marjinal" bir kesim üyesi olarak dolmuşçuların etkin bir baskı grubu oluşturmayacağı gibi üç temel varsayıma dayaniyor.

Nitekim "dolmuşun varlığının" kent morfolojisiyle ilişkili olarak incelendiği bu bölümde Tekeli ve Okyay'ın amaçlarından biri de bu gibi varsayımları sınamak olarak karşımıza çıkıyor. Bu açıdan bakıldığında dolmuşun özgün bir ulaşım sistemi olarak belirli kentleşme süreçlerine koşut olarak ortaya çıktığını görüyoruz. Gerek hız, gerek hizmet esnekliği gerekse de taksi (tamamen özel) ve otobüs (tamamen kamusal) arasındaki farklı statüsü nedeniyle dolmuş sistemi kendine has bir hizmet niteliği sunuyor. Diğer yandan dolmuşçular sahip oldukları hizmet esnekliğine dayanarak değişen maliyetler karşısında farklı stratejiler izleyerek ulaşım ücretlerini dengeleyebiliyor. Son olarak ise marjinal bir kesim üyesi olmasına rağmen dolmuşçular dernekler altında örgütlenerek birçok konuda kendi çıkarlarına baskı oluşturabilmek- 
tedir. Sonuç olarak hızla dönüşen kent morfolojisine bakıldığında ortaya çıkan tablo ne özel araba sahipliğinin toplumun geneline yayılması ne de kamu taşımacılığının yaygınlaştııılması dolmuşa olan ihtiyacı azaltmayacaktır.

Adım adım inşa edilen bu zemin üzerinde Tekeli ve Okyay dolmuşun kent morfolojisiyle olan ilişkisine dair iki temel varsayım geliştirirler. Öncelikle (Varsayım 1) “Bir şehirde kent içi ulaşım aracı olarak dolmuşun bulunması, kentin büyüklügüne bağlıdır. Belli büyüklükten aşağı kentlerde dolmuş bulunmayacak, belli büyüklükten yukarı kentlerde ise dolmuş mutlaka bulunacaktır" (s. 30). Bu temel varsayımı desteklerken bir kişinin 15 dakikadan uzun süren mesafeleri yürümek istemeyeceğini ve kent-içi ulaşımda bu mesafenin uzamasının dolmuşun ortaya çıkmasındaki temel etkenlerden biri olacağını vurguluyorlar. Bu varsayımı desteklemek üzere Türkiye'de nüfusu 50 binden büyük kentlerdeki dolmuş ve otobüs varlığına dair verileri karşılaştırıyorlar. Diğer yandan (Varsayım 2) “Doğrusal biçimdeki kentlerde, dairesel biçimdeki kentlere göre daha alt nüfus düzeyinde dolmuş ortaya çıkacaktır" önermesine dayalı olarak dolmuşun değişen kent morfolojisine göre ortaya çıkabilecek yeni ve farklı hacimdeki taleplere çok daha kolay uyum sağlayabilmesine dayalı olarak özgün bir varlık nedeni olduğunu söylüyorlar. Söz gelimi, kentin bir ucuna hastane ya da üniversite kurulduğunda kente dair yeni bir mesafe referansı olacak bu noktaya dolmuşun ulaşması diğer tüm ulaşım biçimlerinden daha kolay olacaktır (s. 34).

\section{Bölüm 3: Dolmuş Hatlarının Evrimi}

Bir önceki bölümde dolmuşun ortaya çıkış koşulları kentlerin sahip olduğu çevresel ve nüfus artışı gibi özelliklere işaret edilerek tartışılmıştı. “Dolmuş Hatlarının Evrimi" bölümünde ise Tekeli ve Okyay dolmuşun ortaya çıtıktan sonra kentin morfolojisindeki değişime koşut olarak dolmuş hizmetlerinin nasıl dönüştügüünü ele alıyorlar. Dolmuşlarla sunulan ulaşım hizmetinin en temel örgütlenme biçimi olan hatlarının nasıl dönüştüğü kentin morfolojisindeki değişimi de anlamak açısından önemlidir. Nitekim "Bugün, yeni dolmuş hatlarının çoğu, büyük kentlerimizin gelişme biçimine koşut olarak çevreye ve özellikle gecekondu alanlarına hizmet götüren hatlardır" (s. 44) ve adeta kentin mekânsal bedenini saran damarlar olarak görülebilir.

Tekeli ve Okyay, dolmuş hatlarının gelişiminden doğru kent morfolojisine baktıkları bu bölümde bazı nesnel kıstaslar tanımlamaya çalışırlar. Söz gelimi, Ankara'da bir hattın 9-10 km kadar uzayabileceğini, bu mesafeden sonra dolmuşun çalışma doğasına tezat olacağını ve böylece yeni bir hattın 
oluşması gerekeceğini saptarlar. Fakat günümüzde yeni uydu kentleşmelerle birlikte bu mesafe 30 km'ye kadar çıkabilmektedir. İstanbul'da ise Taksim'den Emirgan'a kadar tek bir çizgi üzerinde hareket ediyor olmasına karşın Beşiktaş ve Bebek gibi ara son durakların oluşması ve düz bir çizgi üzerinde birden çok hattın çalışıyor olmasına işaretle hatların gelişiminin belirli işleyiş ilkelerine tabi olduğunu tespit ederler. Dairesel genişleyen kentlerde ise mesafeler uzadıkça iki aks arasındaki alan büyüyecek ve bir noktadan sonra aksları birbirine bağlayacak küçük hatlar ortaya çıkacaktır.

Kent morfolojisinde yaşanan dönüşüme bağlı olarak ortaya çıkan talebi karşılamak üzere kendiliğinden oluşuyor gibi görülebilecek dolmuş hatlarındaki dönüşümlerin gerçekte tabi olduğu başka değişkenler de değerlendirmeye alınmalıdır. Öncelikle dolmuş hatlarının oluşması dolmuşçuların belirli bir geliri kazanmasını sağlamak üzere girişilen bir "pazar paylaşımıdır" (s. 45). Bu nedenle de hatların ortaya çıkışı ve gelişimi sadece nesnel ve fiziksel koşullarla değil belediye ve dernek başta olmak üzere belirli çıkar çevreleri arasındaki pazarlıklarla belirlenir. Ankara ulaşım tarihi açısından önemli bir güzergâh olan Ulus-Bakanlık hattının kentin genişlemesine koşut olarak ortaya çıkan daha uzun hatlar arasında sıkışarak kendiliğinden ortadan kalkmış olması buradaki tartışma açısından önemli bir olgudur.

Bu çerçeveden bir hattın oluşumunda şu adımların izleneceği ön görülebilir: (1) yolculuğun başlangıç ve bitiş noktalarının belirlenmesi, (2) dolmuşun bu hat üzerinde izleyeceği yolu belirleyen ara durakların kararlaştırılması, (3) hatta çalışacak arabaların belirlenmesi ve bunun takibini yapacak bir sorumlu olarak "kâhya" karakterinin ortaya çıkması, (4) taşıma ücretinin belirlenmesi ve (5) hatta çalışacak taşıtlarda bir standardın oluşması (s. 48-51).

Görüldüğü üzere sanıldığının aksine dolmuş̧̧uluk bir "başıbozukluk" değil belirli ihtiyaçlara cevaben farklı aktörler arasında pazarlıklarla oluşan bir taşıma sistemidir. Bir hatta çalışan dolmuşçular, yine sanıldığının aksine, akrabalık ilişkileri ya da aynı mahallede yaşıyor olmaları nedeniyle kendiliğinden toplumsal bir ilişkiler ağının üyesi ve bu nedenle de bir hattın çalışanı değildir. Tekeli ve Okyay'ın işaret ettiği üzere hatların ortaya çıkışı ve gelişmesi aynı zamanda bir marjinal kesim üyesi olarak gördükleri dolmuşçular arasında bir "toplumsal yakınlaşma" oluşmasını da sağladığından hatların oluşturulması gerçekte bir örgütlenme etkinliğidir. 


\section{Bölüm 4: Dolmuş ve Kent Biçimi}

Eğer dolmuşun ortaya çıkışının kentleşme süreciyle bir ilişkisi varsa (Bölüm 2) ve dolayısıyla kent morfolojisindeki dönüşüm dolmuş hizmetlerinin nasıl sunulacağını etkiliyorsa (Bölüm 3) o halde “Dolmuş ve Kent Biçimi” (Bölüm 4) arasında bir ilişki olacaktır. Tekeli ve Okyay, Afyon ve Mersin gibi kentleri de çalışmalarına dâhil ederek, kent biçimi ve dolmuş arasındaki ilişkiyi karşllıklı olarak incelemeye yönelir. Onlara göre dolmuşun örgütlenme biçiminin de kente bir etkisi olduğu düşünülebilir. İlk inceleme hattında (a) kentin nüfus büyüklüğü, (b) kentin (İstanbul gibi doğrusal ya da Ankara gibi yıldız) genişleme biçimi ve (c) arazi kullanımının dolmuş hatlarının nasıl gelişeceği üzerinde tartısmasız bir etkisi vardır. Söz gelimi kentin bir bölgesinin sadece sanayiye ayrılması ulaşım talebini mesai saatleriyle sınırlandıracağından bu aksta bir dolmuş hattının çıkması mümkün olmayacaktır. Oluşan talep ise işveren tarafından örgütlenecek servislerle karşılanacaktır. Yüksek gelirli konut alanlarındaki temel talep ise araba sahipliğinin de yaygın olması nedeniyle taksi dolmuşlarla karşılanacaktır.

Tekeli ve Okyay dolmuş ve kent biçimi ilişkisine dair tartışmayı dolmuşu bağımsız bir değişken alarak, "Dolmuş-minibüs sistemi kendine özgü bir kent biçimi yaratmış mıdır?" (s. 67) sorusu ekseninde de yürütüyorlar. Bu açıdan bakıldığında ise dolmuşa dayalı taşıma sisteminin (a) özel araba kadar esnek olmadığından kopuk (uydu) kentleşme yönelimini zorlaştırıp yıldız biçiminde genişleme ve (2) kentin tek merkezli kalma eğilimlerini güçlendireceğini söylüyorlar. Bu çıarıma dayanarak ise "kent merkezinden kopuk tüketim malları satış odakları (shopping center)" oluşmasını güçleştirirken "merkezi iş bölgesinin toptan ve perakende ticaret merkezi olarak gücünü korumasını" (s. 68) sağlayacağını düşünüyorlar. Tekeli ve Okyay dolmuşun gecekondu alanlarıyla özel bir ilişkisi olduğuna dair bir diğer ön kabul konusunda ise çekimser kalıyor. Evet, dolmuş gecekondu tipi konut alanlarının gerektirdiği esnekliği gösterebilir fakat artık siyasi bir güç elde etmiş gecekondulular mahallelerine otobüs hatları da getirebilmektedir.

\section{Bölüm 5: Kamu Ulaşım Sistemi ve Dolmuş}

"Kamu Ulaşım Sistemi ve Dolmuş" başlıklı beşinci bölümde ise neredeyse kamuoyunda tartışmasız kabul gören; "Dolmuş, ilkel ve artık zaman aşımına uğramış bir sistemdir," "Varlığı bir azgelişmişlik göstergesidir," "Kamu ulaşım sistemindeki yetersizlik nedeniyle dolmuşun varlığı süregitmektedir" ve 
"Modern toplumda kamu ulaşım araçları dolmuşun yerini almalıdır" (s. 85) gibi bir dizi tez tartışmaya açlıyor. Tekeli ve Okyay ise öncelikle 1970 yılında Ankara' da dolmuşun \%43,3 iken otobüs ve troleybüs gibi kamu taşıma sistemleri kullanımının \%20,4 ve İstanbul'da ise bu oranın \%43,3'e karşın \%28 olduğu verisine işaret ederek tartışmaya başliyor. Onlara göre bu ön kabullerin sınanması için üç temel konunun birbiriyle ilişki olarak incelenmesi gerekiyor: (1) yolcuların farklı taşıma sistemleri arasında hangi ölçütlerle seçim yaptığı, (2) işletmecilerin diğer taşıma sistemleriyle rekabet içinde hangi yöntemlerle yolcuları kendine çektiği ve (3) ulaşım hizmetlerinin tümüyle kamusallaşmasının topluma maliyetinin ne olacağı.

1970 Ankara Ulaşımı Ev Anketi ve ODTÜ Şehir Planlama Bölümü öğrencilerinin 1974 yılında gerçekleştirdikleri araştırmalardan elde edilen veriler ışığında konuyu tartışıyorlar. Öncelikle gelir düzeyi arttıkça otobüse binme azalmaktadır ama alt sınıflar için de dolmuş yaygin bir ulaşım tercihidir. Diğer yandan dolmuş en çok taşıt değiştirmeli seyahatlerde ve hızlı bir ulaşıma ihtiyaç duyan yolcu tipinin yaygın tercihi olarak karşımıza çıkıyor. Dolmuş kullanan yolcuların dörtte üçü her zaman dolmuşla seyahat ediyor. 1972 ve 1974 kamu ulaşım zamlarında otobüs yolcularının dolmuşa kaymış olması ise ücretin bu tercihte önemli bir değişken olduğuna işaret ediyor.

Diğer yandan yine araştırma kapsamında "Dolmuş çalışmasa ne yapars1nız?" sorusuyla dolmuş yolcularının \%20'sinin zorunlu durumlarda otobüse binmek yerine yürümeyi tercih edeceğini görüyorlar. Bunun nedeni ise dolmuş yolcularının otobüsün yavaş, bekliyor ve rahatsız olduğuna dair kabulleri (s. 94). Bu bulguyu sınamak için oldukça ilginç bir olanak ediniyorlar. 1011 Kasım 1970 tarihlerinde Türkiye Şoförler ve Otomobilciler Federasyonu'nun Türkiye çapında düzenlediği "kontak kapatma boykotu" esnasında Karayolları Genel Müdürlüğü kapsamlı bir gözlem gerçekleştiriyor. K1zılay - Ulus hattında 11 sayım noktasından gelen verilere göre 5485 dolmuş sıfıra inerken otobüs sayısı 1034'ten (sefer sayısı arttığı için) 1074'e çıkmıştır. Buna göre dolmuşların çalışmadığı bu iki günde otobüsler dolmuş yolcusunun ancak \%56'sını taşımış ve kalan yolcuların yürümeyi tercih ettiği görülmüştür.

Diğer yandan işletmeci açısından dolmuş ve kamu ulaşım sistemleri ilişkisine bakıldığında üç temel varsayım belirlenebilir: (a) birbirine tümüyle bağımlıdır, (b) birbirine yarı bağımlıdır, (c) birbirinden bağımsızdır. Tekeli ve Okyay derledikleri veriler ışığında dolmuşların doruk saatlerde kamu ulaşım sisteminin açığını kapatma işlevini yerine getirdiğini fakat doruk dışı saatlerde ise kamu ulaşım sistemiyle yarıştığını ve bu yarışmadan kamu ulaşım 
sisteminin zararlı çıkmakta olduğu (s.111) sonucuna varıyor ve aradaki ilişkiyi yarı-bağımlı olarak değerlendiriyor.

\section{Bölüm 6: Dolmuşun Ekonomisi}

Bu bölümdeki maliyet tartışması "Dolmuşun Ekonomisi" başlıklı altıncı bölümde devam ediyor. Bu konuda da kamuoyunda dolmuşun otobüse göre daha pahalı maliyete sahip bir ulaşım sistemi olduğuna dair genel kabul görür bir tez tartışmanın odağında yer alıyor. Tekeli ve Okyay'a göre kâğıt üzerinde maliyet hesaplamasının basit bir denklemi vardır: "Harcamayı oluşturan öğeler ulaşım altyapısı ve taşıtların yatırım giderleri, yakıt, bakım, onarım ve personel gibi işletme giderleridir. Bu harcamalar taşınan yolcu sayısına ve kilometreye bölünerek birim taşıma harcamaları elde edilir" (s.119). Bu denkleme göre hesaplama yapıldığında evet yolcu başına giderde otobüs, yolcukilometre başına giderde ise minibüs daha düşük maliyete sahiptir. Fakat bu hesaplamayı zorlaştıran iki temel etken vardır: (1) dolmuş̧̧ular genelde tek sürücü ve uzun saatler çalışarak emek ve (2) sadece hurda değeri kalmış araçlarının aşınma payı ve kasko giderlerinden kaçınarak üretim aracının yenilenmesi maliyetlerini düşürürler. Bu iki strateji sayesinde koşula göre esneklik sağladığından maliyet hesabının genel geçer bir denklemle hesaplanması güçleşecektir.

Buna karşın dolmuş sisteminin bir kamu ulaşım sistemi olarak otobüslerden farklı bir tarife stratejisi vardır. Öncelikle iniş-biniş olasılığının yüksek olduğu merkezi iş bölgelerinde ücret daha hızlı artırılarak uzun mesafe yolcusunun en kısa sürede inmesi sağlanmaya çalışılır. İkinci olarak hatların uç kesimlerinde talebi daha az olacak yolcular için dolmuşun daha çekici kılınmasıdır. Üçüncü olarak ise okul ve hastane gibi genellikle merkezi iş bölgesinin sınırlarında etkinlik oluşturan kurum yolcuları için ücret düşük tutularak otobüse rekabet oluşturulur. Ücretin uzaklığa göre artışı tüm bu tarife stratejilerinin temel belirleyenidir ve dernek bu stratejilerin çalışabilmesi için belediye üzerinde baskı kurmaya çalışır. Kamu taşımacılığının hem farklı ücretlendirme stratejileri kullanma esnekliğinden hem de dernek gibi bir lobi desteğinden yoksundur. Fakat diğer yandan otobüsler örgütlenme biçimi nedeniyle yakıt, bakım ve lastik giderleri gibi kilometre başına maliyetle doğrudan orantılı harcamalar açısından önemli bir avantaja sahiptir. Tüm bu harcamalar otobüs için toplam giderin $\% 20,5$ 'ine tekabül ederken minibüslerde bu oran $\% 57$ gibi bir orana çıkabilmektedir. 
Sonuç olarak Tekeli ve Okyay'a göre "Dolmuşun birim taşıma giderleri açısından otobüsle yarışabilmesi ve belki de onu geçmesi dolmuş sisteminin kendi içindeki emek sömürüsüyle sağlanmaktadır" (s. 140). Bu nedenle bir küçük girişimci uğraşısıdır ve kimi dolmuşçular için geçici bir iş olabilir ama kamuoyunda yaygınca paylaşılan ön kabuller ekseninde olacağı beklenemez.

\section{Bölüm 7: Dolmuş Yolcuları}

Çalışmanın en özgün yanı, dolmuşçular ve dolmuş yolcularıyla soru kâğ1dına ve mülakatlara dayalı gerçekleştirilmiş araştırma kısmıdır. Bölüm 7 “Dolmuş Yolcuları" ve Bölüm 8 ise "Dolmuşçular Kimlerdir?" başlıkları altında bu araştırmanın bulgularına odaklanır. Dolmuş yolcularının genel bir görünüşünü çıkarmak üzere çalışan dolmuş sayısına göre 17 hat belirlenmiş ve her hatta en az 50 yolcuya sabah işe geliş ve akşam işten dönüş saatlerinde oluşan kuyruklarda 12 soruluk anket uygulanmıştır. Anket çalışması "dolmuş yolcuları kimlerdir, kamu ulaşım sistemi yolcularından nasıl farklılaşırlar, dolmuş yolcuları neden dolmuşu seçerler, dolmuşun hangi özellikleri bu tercihi belirler, yolculuk sırasında, yolcular ve dolmuş sürücüsüyle nasıl ilişkiler olur" (s. 148) gibi konu başlıklarına odaklanmıştır.

Diğer yandan görüşmelerin durakta bekleyen yolcularla yapılması nedeniyle soru sayısı sınırlı tutulmuş ve kapalı uçlu soru tipi tercih edilmiştir. Anket sadece dolmuş yolcularıyla gerçekleştirildiğinden veriler otobüs yolcularıyla karşılaştırmalı bir tartışmaya olanak vermemektedir. Diğer bir sınırlılık ise araştırmanın Temmuz ayında okullar kapalıyken gerçekleştirilmiş olmasıdır. Bu sınırlılıklarla 902 anket tamamlanmıştır. Ankete katılan dolmuş yolcuların \%74,4'ü erkek kalanı kadındır. Dolmuş kullanım amacı olarak en yüksek oranda "eve dönüş" $(\% 44,2)$ ve hemen ardından "çalışmaya gidiş" $(\% 35,7)$ belirtilmiştir. Dolmuş yolcularının çok büyük bir kısmı (\%64,7) 20 ila 34 yaş aralığındadır ve yaş ilerledikçe dolmuş kullanımının azaldığı görülmüştür. Dolmuş yolcusunun en çok kullandığı taşıt biçimine dair tercihlerde sıralama ise dolmuş $(\% 76,3)$, otobüs $(\% 10,3)$, özel oto $(\% 2,8)$, taksi $(\% 1,9)$ ve tren $(\% 1,1)$ olarak saptanmıştır. Yolcuların $\% 4$ 'ü ise dolmuş ve otobüsü birlikte kullandığını belirtmiştir. En sık dolmuş kullanımı ise Ulus-Küçükesat hattında tespit edilmiştir. Yolcuların mesleki görünüşünde işçi ve küçük esnaf oldukça az çıkarken "I. Küme" olarak andıkları (serbest, memur, teknik yardımc1) meslek grubu en yaygını olarak tespit edilmiştir. Öğrenciler arasinda ise otobüs (\%32,1) açık farkla dolmuşun (\%18) önüne geçmektedir. 
Dolmuş yolcularının tercihinde otobüsün "çok yavaş", "çok bekliyor", "çok sıkışık ve rahatsız" olması (s. 163) en yaygın nedenler olarak belirtilmiştir. Tekeli ve Okyay dolmuşların da kimi zaman kapasitelerinin üstünde taşımacılık yapıyor olmasına işaretle son nedeni ilginç buluyor. Dolmuş konusundaki şikâyetler ise eğitim düzeyine göre azalış göstermiş "hiç okumamışlar" arasında "şikâyetim yok" seçeneği en yüksek düzeyde tespit edilmiştir. Dolmuştan şikâyetler ise "keyfi hareket ediyor", "trafiği bozuyor" ilk iki s1rayı alırken, şoförlerin zevksiz müzik çalması ve fazla yolcu alması diğer rahatsızlıklar olarak belirtilmiştir.

\section{Bölüm 8: Dolmuşçular kimlerdir?}

Dolmuşçularla gerçekleştirilen araştırma ise 20 ila 40 dakika arasında süren 56 soruluk bir görüşme formuna dayanıyor. Görüşmeler için sefer sıklı̆̆ının az olduğu öğlen ile öğleden sonrası dolmuşçuların sırada beklediği zaman aralığı tercih edilmiş ve toplamda 314 görüşme yapılmış. Dolmuş̧̧uların kim olduğu öncelikle "Kente göçer göçmez dolmuşçuluğa geçilebilir mi? Dolmuşçuluğa daha çok hangi mesleklerden geçiş vardır? Dolmuş̧̧uluk hangi mesleklere göre ileri bir aşama sayılır?" gibi konular üzerinden çalışılmış. Görünümün geneline bakıldığında dolmuşçuların yarısının son 10 yılda Ankara'ya yerleştiğini ve çiftçi ailelerden geldiği görülüyor. Babası işçi, küçük esnaf ya da zanaatkâr olanların oranı \%14,4 iken baba mesleği şoför olanların oranı $\% 9,6$ olarak tespit edilmiş. Dolmuşçuların kendisi ise \%44 oranında taksicilik, otobüsçülük, kamyon sürücülüğü, uzun yol şoförlüğü ve muavinlik gibi işlerden sonra dolmuş şoförü olarak çalışmaya başlamış. Uzun yol şoförleri akşamları evde yatabilmek için dolmuşçuluğa geçtiğini belirtmiş.

Çiftçilikten (doğrudan kente göçle birlikte) dolmuş̧̧uluk yapmaya başlayanların oranı ise \%12,7 olarak tespit edilmiş. Tekeli ve Okyay bu veriyi "her ehliyet alan kente gelerek dolmuşçuluk yapmaktadır" genel kanısının yanlışlığına işaret ettiği yönünde okuyor (s. 180). Görüşülen dolmuşçuların \%22,3'ü ise dolmuşçuluğa geçmeden önce birçok başka işte çalışmış olduğunu söylemiş. Diğer bir önemli veri ise ne zamandır bu işin yapıldığıyla ilgili soruya verilen cevaplarda karşımıza çıkıyor. Dolmuşçuların \%17,1'i son bir yıl içinde, \%4,8'i ise son bir haftadır bu işe başlamış. Son on yıldır dolmuşçuluk yapanların oranı ise $\% 8,9^{\prime}$ da kalmış. Son bir yıldır bulunduğu hatta çalışanların oranı \%28,5 iken son bir haftada mevcut hatta çalışmaya başlamış olanların oranı ise \%10,6 olarak tespit edilmiş. Görüşülen kişilerin \%55'i “çaresizlikten" dolmuşçuluk yaptığını belirtmiş. 
Katılımcların \%30,3'ü akraba yardımıyla dolmuşçuluğa başladığını ve $\% 37,7$ 'si ise başka birinin aracında şoförlük yapmakta olduğunu belirtmiş. Minibüs sahibi olanların \%90'u ise sadece tek araç sahibi olduğunu belirtmiş. Fakat Tekeli ve Okyay araçların eşlerin üzerine yapılabildiğine işaretle bu oranın güvenilir olamayabileceğini belirtiyor. Ayn zamanda belediyede otobüs şoförü olarak çalışıp minibüs sahibi olan kimseler olduğunu da ekliyorlar. Dolmuşçulara dair bir diğer genel kanı olan büyük oranda gecekonduda yaşadıkları düşüncesinin de doğru olmadığı bu araştırmada ortaya çıkmış.

Dolmuşçuların \%83,4'nün medeni durumu evlidir ve \%57,3'ü günde 1011 saat ve üzerinde çalıştığını belirtmiştir. Günde 8-9 saat çalışanların oranı ise $\% 34,9$ olarak tespit edilmiştir. Dolmuşçuların \%51,9'u sadece Pazar günü tatil yaparken haftada iki gün tatil yapanların oranı sadece $\% 3,9$ olarak belirlenmiştir. Araştırmaya katılanların \%45'i tek, \%54'ü ise iki sürücü olarak çalıştığını ve \%57,7'si hâlihazırda borçlu olduğunu söylemiştir. Dolmuş̧̧ular en çok özel otolardan ve trafik polisinden şikâyetçi olurken yolcular konusunda ise olmadık yerde inmek istemelerinden, inerken kapıyı vurmalarından ve bozuk para bulundurmamalarından rahatsız olduklarını belirtilmişlerdir.

Tekeli ve Okyay "Varsayıldığının aksine dolmuşçular hiç de 'anarşi' içinde gözükmemektedir" (s. 200) sözleriyle dolmuşçuların belirli ilkeler çerçevesinde çalıştı̆̆ına ikna oluyorlar. Söz gelimi, “Dolmuş̧̧ular birbirinin hakkını korur mu?" sorusuna gelen \%83,7 oranında "Evet" cevabı onlar için bunun bir göstergesi. Görüşülen dolmuşçuların \%24,7'si mevcutta çalıştığı hattı değiştirmek istediğini belirtmiş. Bu talebi dile getiren 78 dolmuş̧̧udan 62 'si başka hatların kazancının iyi olmasını neden olarak belirtirken diğer hatlarda müşterilerin daha iyi olduğunu ya da oturdukları semtler üzerindeki hatları tercih ettiğini söylemişlerdir. Dönemin en sevilen hatlarıysa sırasıyla şu şekilde tespit edilmiş: Ulus - Abidinpaşa, Bahçeli - Dörtyol, Ulus - Küçükesat, Ulus - Seyranbağları, Ulus - Siteler, Ulus - Keçiören, Ulus - Etlik. Tekeli ve Okyay bir hattın birden fazla etkinlik alanına değiyor ise gün içinde yolcu tipi çeşitliliğinin ve dolayısıyla iş yoğunluğunun artacağına işaretle bu tercih s1ralamasının anlaşılabileceğini söylüyor.

Görüşmecilerin \%55'i dolmuşçuluğu bırakmak istediğini belirtmiş. Yolcuların \%32,9'nun dolmuşçuluğu oldukça kazançlı bir iş olarak görmesine karşın dolmuşşular işin yorucu ve gelirinin düşük olduğu görüşündedir. En çok geçmek istedikleri meslekler ise memurluk (\%39), tüccarlık (\%27,8) ve taksicilik (\%7) olarak belirtilmiştir. Önceki mesleği şoförlük olanların yarısı ise yine dolmuşçu olmak istediklerini söylemiş. Tekeli ve Okyay dolmuşçuluğu bırakan kümeyle görüşme yapmadıkları için dolmuşçuluğa karşı belirtilen 
bu olumsuz görüşleri birer tutum olarak değerlendirmenin daha doğru olacağını söylüyor.

Dolmuş şoförü ve yolcularla ayrı ayrı yapılan görüşmelerin en önemli ortak konusu bu iki küme insan arasındaki etkileşime dair sorular. Yolculara yönelik yolculuk esnasında şoförle "sohbet etme" sorusuna kadınlar erkelere, yüksek eğitimliler düşük eğitimlilere, apartmanda oturanlar gecekonduda oturanlara göre daha az oranda "Evet" demişler. Tekeli ve Okyay yolcuların \%26'sına karşın dolmuş̧̧uların \%47,9 gibi yüksek bir oranda "Evet" cevabı vermiş olmalarını açıklanmaya muhtaç bir durum olarak görüyor. Araştırma kapsamında "sohbet etme" lafzından ne anladıklarının sorulmadığını ama bu oranlar arasındaki farka bakılırsa "Ya dolmuşçular kendi başlarına sohbet etmiştir ya da yolcular kimi konuşmayı 'sohbet' den saymamıştır”' (s. 202) ifadesiyle ortada ilginç bir durum olduğunu söylüyorlar. Bugün açısından da önemli olacağını düşündüğüm bu verileri yolcu ve dolmuş şoförü cevaplarına göre sıralanmış olarak sunmak isterim.

Tablo 1. Çizelge 8.19'a göre hatlara göre dolmuşta sohbet edenler (s. 203).

\begin{tabular}{|c|c|c|c|c|c|c|c|}
\hline \multicolumn{2}{|c|}{ Dolmuş Hatları } & \multirow{2}{*}{$\begin{array}{l}\begin{array}{l}\text { Yolcu } \\
\%\end{array} \\
41.4 \\
\end{array}$} & \multirow{2}{*}{$\begin{array}{l}\begin{array}{l}\text { Dolmuşçu } \\
\text { \% }\end{array} \\
81.8\end{array}$} & \multicolumn{2}{|c|}{ Dolmuş Hatları } & \multirow{2}{*}{$\begin{array}{l}\begin{array}{l}\text { Yolcu } \\
\%\end{array} \\
41.4\end{array}$} & \multirow{2}{*}{$\begin{array}{l}\begin{array}{l}\text { Dolmuşçu } \\
\%\end{array} \\
81.8 \\
\end{array}$} \\
\hline Ulus & Bakanlık & & & Ulus & Bakanlık & & \\
\hline Ulus & Keçiören & 40.5 & 50 & Ulus & Karşıyaka & 27 & 72.7 \\
\hline Ulus & Etlik & 38.2 & 45.5 & Ulus & Siteler & 23.4 & 60 \\
\hline Ulus & Balgat & 34.5 & 18.2 & Ulus & K.Esat & 13.3 & 60 \\
\hline Ulus & Çinçin & 34.5 & 50 & Aydınlık & Çankaya & 29.1 & 58.2 \\
\hline Ulus & Mamak & 32.7 & 26.3 & Kizilay & Dikmen & 23.3 & 54.5 \\
\hline Ulus & Topraklık & 32.7 & 50 & Ulus & Keçiören & 40.5 & 50 \\
\hline Aydınlık & Çankaya & 29.1 & 58.2 & Ulus & Çinçin & 34.5 & 50 \\
\hline Ulus & Karşıyaka & 27 & 72.7 & Ulus & Topraklık & 32.7 & 50 \\
\hline Ulus & Siteler & 23.4 & 60 & Ulus & Etlik & 38.2 & 45.5 \\
\hline Kızılay & Dikmen & 23.3 & 54.5 & Ulus & Abidinpaşa & 20 & 40 \\
\hline Ulus & Abidinpaşa & 20 & 40 & Kizilay & Y.Ayrancı & 13.3 & 40 \\
\hline Bahçeli & Dörtyol & 18.6 & 39.1 & Bahçeli & Dörtyol & 18.6 & 39.1 \\
\hline Ulus & K.Esat & 13.3 & 60 & Ulus & Seyran & 5 & 30 \\
\hline Kizilay & Y.Ayranc1 & 13.3 & 40 & Ulus & Mamak & 32.7 & 26.3 \\
\hline Ulus & Seyran & 5 & 30 & Ulus & Balgat & 34.5 & 18.2 \\
\hline
\end{tabular}

Yolculuk esnasında sohbet ettiğini söyleyen yolcu ortalaması \%26 iken dolmuşçu ortalaması $\% 47,9$ olarak saptanmıştır. 
Tablo 2. Çizelge 8.20'a göre hatlara göre göz tanışı olanlar (s. 205). (s. 203).

\begin{tabular}{llllllll}
\hline \multicolumn{2}{l}{ Dolmuş Hatları } & $\begin{array}{l}\text { Yolcu } \\
\text { \% }\end{array}$ & $\begin{array}{l}\text { Dolmuşçu } \\
\mathbf{\%}\end{array}$ & Dolmuş & Hatları & $\begin{array}{l}\text { Yolcu } \\
\%\end{array}$ & $\begin{array}{l}\text { Dolmuşçu } \\
\%\end{array}$ \\
\hline Ulus & Topraklık & 53.1 & 81.3 & Ulus & Seyran & 45 & 100 \\
\hline Ulus & Karşıyaka & 48.6 & 90.9 & Ulus & Karşıyaka & 48.6 & 90.9 \\
\hline Ulus & Bakanlık & 48.3 & 81.8 & Ulus & Etlik & 44.1 & 90.9 \\
\hline Ulus & Çinçin & 48.3 & 50 & Ulus & Dikmen & 40 & 90.9 \\
\hline Ulus & Abidinpaşa & 47.5 & 80 & Aydınlık & Bakanlık & 48.3 & 81.8 \\
\hline Aydınlık & Çankaya & 45.8 & 56.7 & Ulus & Topraklık & 53.1 & 81.3 \\
\hline Ulus & Seyran & 45 & 100 & Ulus & Abidinpaşa & 47.5 & 80 \\
\hline Ulus & Etlik & 44.1 & 90.9 & Ulus & Keçiören & 43.2 & 75 \\
\hline Ulus & Keçiören & 43.2 & 75 & Ulus & K.Esat & 16.7 & 70 \\
\hline Ulus & Mamak & 41.8 & 52.6 & Ulus & Balgat & 34.5 & 63.6 \\
\hline Ulus & Siteler & 40.4 & 60 & Ulus & Siteler & 40.4 & 60 \\
\hline Kızlay & Dikmen & 40 & 90.9 & Kızlay & Çankaya & 45.8 & 56.7 \\
\hline Ulus & Balgat & 34.5 & 63.6 & Ulus & Mamak & 41.8 & 52.6 \\
\hline Bahçeli & Dörtyol & 26.5 & 51.6 & Bahçeli & Dörtyol & 26.5 & 51.6 \\
\hline Kızlay & Y.Ayrancı & 23.3 & 50 & Kızlay & Çinçin & 48.3 & 50 \\
\hline Ulus & K.Esat & 16.7 & 70 & Ulus & Y.Ayrancı & 23.3 & 50 \\
\hline & & & & & & \\
\hline
\end{tabular}

Yolculuk ettiği araç şoförüyle yüz aşinalığı olduğunu söyleyen yolcu ortalaması \%39 iken dolmuşçu ortalaması \%65,6 olarak saptanmıştır. Tekeli ve Okyay hatlar arasında yolcu ve dolmuş̧̧u cevapları arasındaki farkı yorumlarken kişilerin "genellikle daha üst toplum katmanlarından başka kişilerle sohbet ettiklerini söyleme eğilimi" (s. 203) gösterdiğini düşünüyorlar. Göz aşinalığ ise "kentin güvensiz ortamı içinde, bir güvence olma niteliği" (s. 204) taşıyor olduğuna işaretle açıklıyorlar.

\section{Bölüm 9: Dolmuşçuların Örgütlenmesi}

Son inceleme konusu olarak dokuzuncu bölüm “Dolmuşçuların Örgütlenmesi" meselesine odaklanıyor. 1964 yılından çıkarılan 507 sayılı "Esnaf ve Küçük Sanatkârlar Kanunu" uyarınca farklı iş dallarında dernekleşmenin önü açldııtan sonra "Ankara Umum Otomobilciler ve Şoförler Derneği" kuruluyor. Fakat hemen sonrasında dolmuş taşımacılığındaki farklı biçimleri temsilen "Ankara Minibüsçüler Esnafı Derneği" gibi farklı dernekler ortaya çıkıyor. Tekeli ve Okyay'a göre Belediye ve İl Trafik Komisyonu olmak üzere pazara dair kural ve kısıtlamaları belirleyen iki aktöre karşın bu dernekler dolmuşçuların çıkarlarını gözetecek bir baskı odağı işlevi kazanıyor.

Tekeli ve Okyay çalışmayı gerçekleştirdikleri dönemde dönemin İçişleri Bakanı Oğuzhan Asiltürk'ün başta Ankara ve İstanbul gibi büyük şehirlerde 
plaka tahdidini kaldıracağını açıklaması üzerine yaşananları gözlemleme olanağı buluyor. Söz gelimi 23 Temmuz 1976 tarihinde Ankara'da dolmuş ve taksi şoförleri İçişleri Bakanlığı kavşağını arabalarıyla kapatarak bir gösteri yapmış ve müdahale etmek isteyen polisle çatışmışlardır. Dönemin Ankara Büyükşehir Belediye Başkanı Vedat Dalokay konunun İçişleri Bakanlığının yetkisinde olmadığını söylemiş ve AP-MSP iktidarının konuyu seçimlerde kullanmak amaciyla siyasileştirdiğini iddia etmiştir. Diğer yandan plaka tahdidinin kaldırılması yönünde en güçlü lobiyi oto üreticilerinin yaptı̆̆ı görülmüştür. Taşıma araçlarının yeni model minibüslerle standartlaşmaya başladığı bir dönemde mümkün olduğunca çok araç satmak isteyen bu yeni aktörün etki gücüne dair bir şey söylemek elimizde veri olmadığından güç gözüküyor. Fakat diğer yandan, dernekler 1968 yılında maliyetleri azaltmak amacryla bir yedek parça kooperatifi kurmayı denemiş fakat büyük liman kentlerindeki ithalatçı firmaların tekeliyle karşılaşmış ve plaka tahdidinin korunması mücadelesinde gösterdikleri başarıyı bu alanda sergileyememişlerdir. Dolayısıyla bu gibi aktörlerin de dolmuş meselesinin anlaşılmasında yeri olacağı düşünülmelidir.

Tekeli ve Okyay'a göre bir hatta plakalı bir dolmuş sahibi olmak dolmuşçular açısından bir anlamda emeklilik işlevi görür. Plaka tahdidi bu anlamda en önemli mücadele alanı olarak karşımıza çıkar. Diğer yandan "dolmuşta hizmet niteliğinin düzenlenmesi" kapsamında (a) dolmuş geçiş yollarının, (b) son durak ve dönüş yerlerinin, (c) dolmuş kalkış aralıklarının belirlenmesi, (d) ana ve ara durak yerlerinin gösterilmesi, (e) dolmuş içinde sigara içilmemesi ya da müzik çalınmaması türünden yasaklar ve (f) 15 dakikada bir kalkma ve son durağa kadar gitme zorunluluğu gibi kuralların belirlenmesi birer mücadele alanı olarak görülebilir.

Sonuç olarak, bir sektör olarak taşımacılık alanında rantın oluşumu birden çok aktör arasındaki bilek güreşine dayalıdır ve dernekler bu alanda dolmuşçuları temsil eden aktör olarak karşımıza çıkmaktadır. Nitekim uzun yıllar dolmuşçuluk yapmış, meslek örgütlerinde yer almış kimi temsilcilerin farklı partilerden milletvekili olması bu meselenin anlaşılması açısından önemli göstergelerdir. Fakat diğer yandan, derneklerin kimin çıarını temsil ettiği başka bir tartışma konusudur. Dolmuş şoförlerinin sosyal güvenceye kavuşması sürecinde dernek SSK yerine Bağ-Kur'a dayalı bir çözümü desteklemiştir. Zira ilk seçenek araç sahibi olan ve "işçi-şoför" çalıştıran üyelere bağlayıcı bir yükümlülük olacakken ikinci seçenek sahipliği olsun olmasın her şoförü kendinden sorumlu hale getireceği için taraflı bir tutumdur. Gerek artan ta- 
şıma talebine karşın plaka kısıtlamasını savunarak gerekse de Bağ-Kur'a bağlanmayı destekleyerek derneklerin araç sahibi olan dolmuşçuların çıkarları doğrultusunda çalıştı̆̆ görülmektedir. Tekeli ve Okyay bu bölümde yürüttükleri tartısmanın dayanağı olarak dönemin gazete haberleri ve derneklerin yaptığı açıklamalardan geniş bir ekler kısmı da sunmaktadır.

\section{Bölüm 10: Dolmuşun Geleceği}

Son bölüm ise "Dolmuşun Geleceği" başlığıyla çalışma içerisinde tartışılan meselelerin iki temel soru ve üç farklı düzeyde tartışılmasına ayrılıyor. Tartışmanın eksenini çizen iki soru: “Gelecekte dolmuş olacak mıdır?” ve "Olacaksa, bu dolmuşun niteliklerini nasıl değiştirecektir?" olarak kuruluyor. Düzeyler ise (1) dünya ekonomisindeki değişikliklerin ve teknolojik ilerlemenin kent içi ulaşımın örgütlenmesine ve dolmuşa etkisi, (2) ülke ekonomisindeki ve siyasal yapıdaki değişikliklerin dolmuş olgusuna yansıması ve (3) dolmuş örgütlenmesinin kendi dinamiği içinde oluşan değişmeler olarak tanımlanıyor.

Bu çerçeveden bakıldığında gelecekte yeni ve daha ucuz enerji kaynaklarının yaygınlaşmasına koşut olarak taşımacılık alanında bütün dünyada köklü değişimler beklenebileceği fakat bir çeper ülke olarak Türkiye'nin bu dönüşümlere uyum sağlamak konusunda gecikmeler yaşayacağı, yine kentleşmenin devam etmesine koşut olarak ulaşım konusunda talebin artacağı ama tümüyle kamu kaynakları tarafından karşılanamayacağı için de dolmuşun (kamu taşımacılığının tamamlayıcısı olarak) varlığını sürdüreceği sonucuna varılıyor. Bu konunun bir "savaşım" alanı olarak kalacağını ve dernekler tarafından temsil edilen dolmuşçuların karşısına kamuyu temsilen sendikaların ağırlığını koyup koymayacağına dayalı olarak şekil alacağını ekliyorlar.

\section{Sonuç: Dolmuşun Labirent Olan Hikâyesi}

"Kızılay. Güvenpark. Biraz daha yürüyelim. Buradaki insan hareketi bir yerlere yetişmesi gerekmeyen insanı bile acele ettirebilir. Her geçişte, aslında buranın bir park olduğunu düşünüp sonra buna şok olmakla geçen 2 dakika sonrasında 8,5 basamak tırmanıp bir maviliğin içine girmiş oluyoruz. Gökyüzü mü o mavi? Pek değil şimdi. Burası bir otopark. Bir 8 şeritli yol trafiği. Bir kebapçı. Burada bir "Kullanılmayan Kaldırım Taşlarıyla Topografya Tasarlama Yarışması" Sergisi var. E bu Emek dolmuşu değil mi? Yok abla bu 
geçmez arkaya bak oradan. Post-gerçeklik. Labirent. Mavi. Dolmuş mavisi. Tasarlanmış mekânlara ait parıltılı kesitler, planlar, perspektifler, yok efendim kesit perspektifler, 1/20 detaylar vesaire görmeye alışmış gözlerimiz için alternatif bir mimari çizim seti hazırladım. Burası belki de Ankara'nın en tanıdık ve en belirsiz kamusal (olamayan) ve (yürüyemeyen) yayalara ait (alternatif) mekânı. Mavi labirent! Alternatif bir mekân deneyimi olarak nasıl çalışmış Alternatif Mekân mimarlarımız bakalım" (Sarıca, 2019).

Tekeli ve Okyay'ın bu özgün çalışması kente dair toplumsal olguların nasıl çalışılabileceğine dair getirdiği yaklaşımla kent çalışmaları açısından önemini bugün de koruyor. Çalışma kapsamında geliştirdikleri varsayımların ne ölçüde gerçekleşmiş olduğunu yeni çalışmalarla sınamadan tartışmak hem güç olacak hem de Dolmuşun Öyküsü'nü tanıtmayı amaçlayan bu yazının sinırlarını zorlayacaktır. Böyle bir çabaya girişmek yerine bu yazıda çalışmanın önemi ve özgünlüğü tartışılmaya çalışılmıştır. Fakat dolmuşun çeper ülke kentleşme süreçlerinde ulaşıma dair ortaya çıkan gereksinmelere koşut olarak şekillendiğine dair temel saptamanın bugün açısından önemli bir referans olacağı not edilmelidir. Sarıca'nın bugün Güven Park'a bakarken gördüğü "mavi labirent" ve dolmuş camların süsleyen isimliklerde devlet hastaneleri gibi kurumların yerini kentin dört bir köşesine yayılmış elliye yakın AVM'nin almış olması dolmuşun (uzun) öyküsünün halen devam ettiğine işaret ediyor.

\section{Görsel Ekler}

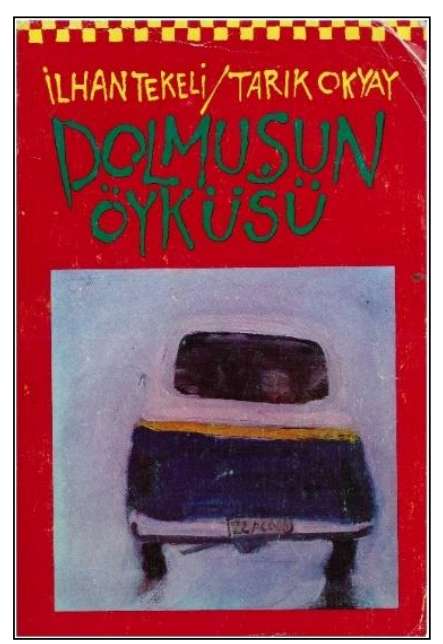

Görsel 1. Kitabın Suha Özkan tarafından yapılan kapak düzeni 


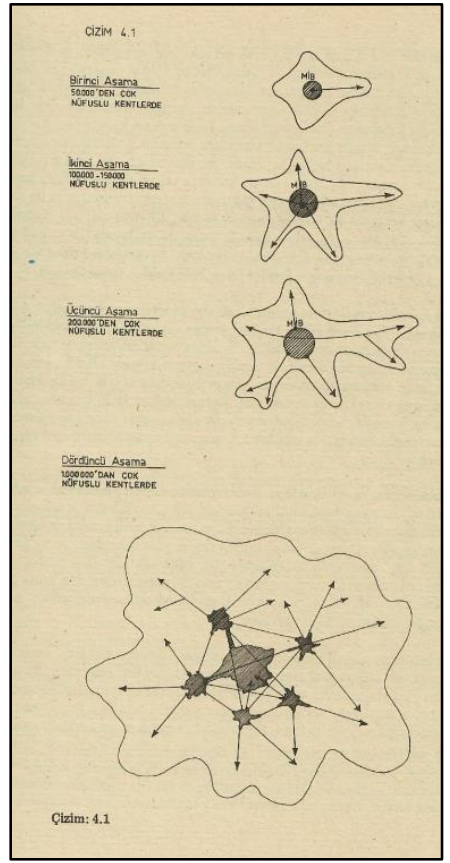

Görsel 2. Kentin değişen morfolojisine göre dönüşen dolmuş hatları. Çizim: 4.1 (s. 61)

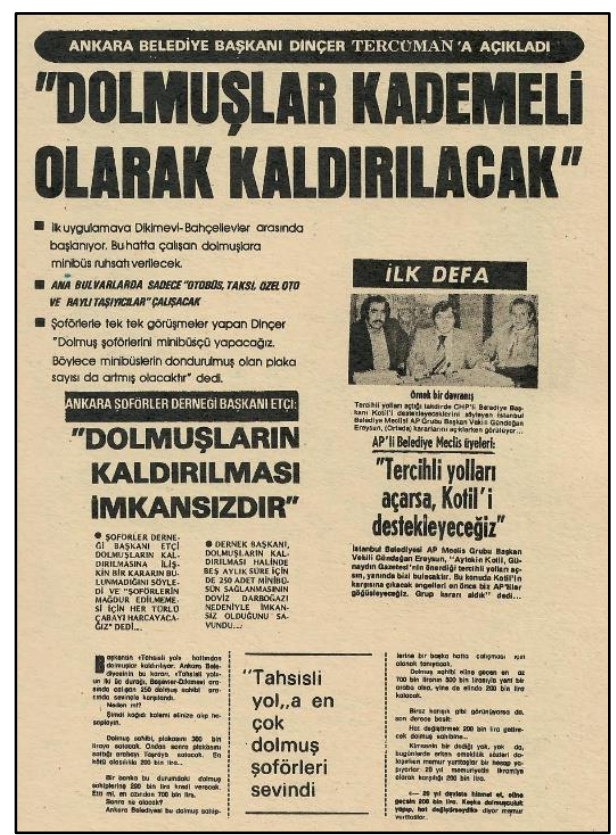

Görsel 3. Tercüman ve Günaydın (17 Aralık 1978), Cumhuriyet (14 Ocak 1979) (s. 83) 


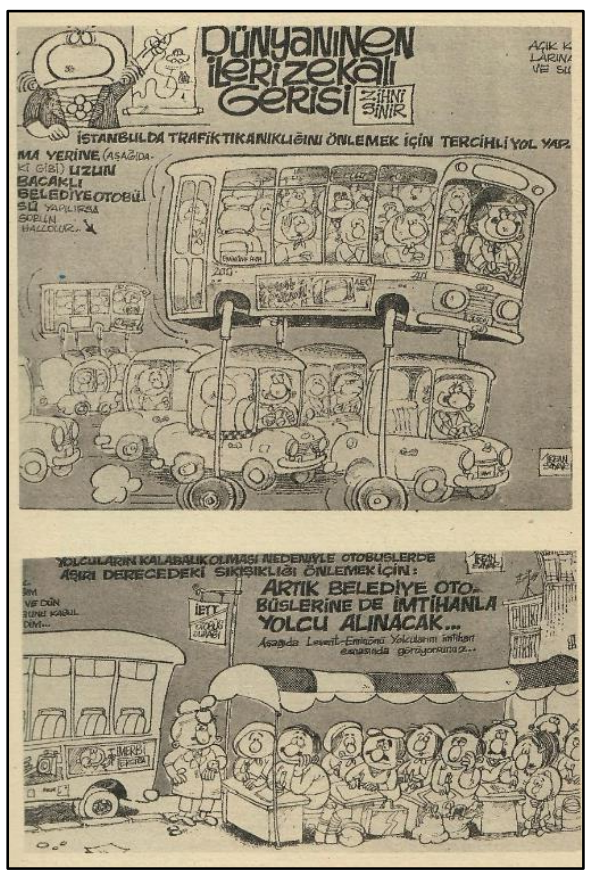

Görsel 4. İrfan Soyer tarafından çizilen ve Mikrop'da yayımlanan karikatür (s. 75)

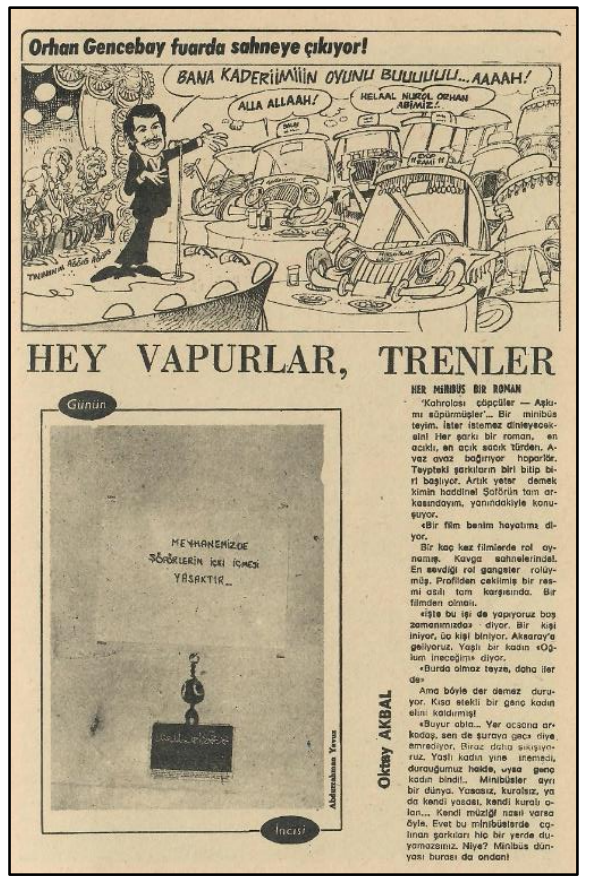

Görsel 5. Gırgır'da yayımlanan bir karikatür (s. 175) 


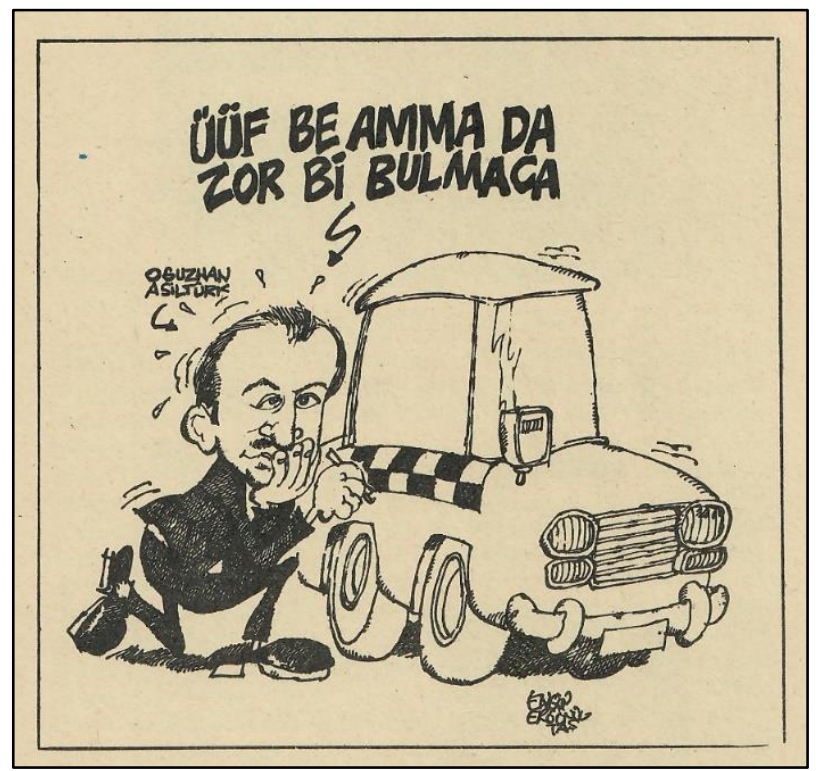

Görsel 6. Ergin Ergönültaş'ın dönemin İçişleri Bakanı Oğuzhan Asiltürk'ün gündeme getirdiği plaka tahdidinin kaldırılmasına dair Politika dergisi için çizdiği karikatür (s. 263)

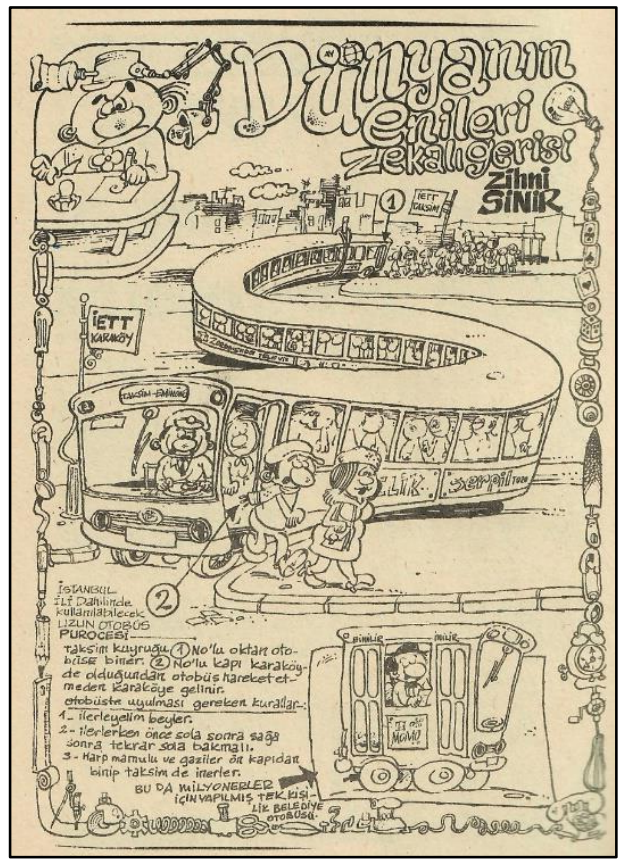

Görsel 7. İrfan Soyer ve Yavuz Aran tarafından Gırgır için çizilen karikatür. Günümüzün metrobüs olgusuna dair bir kehanet adeta (s. 291) 


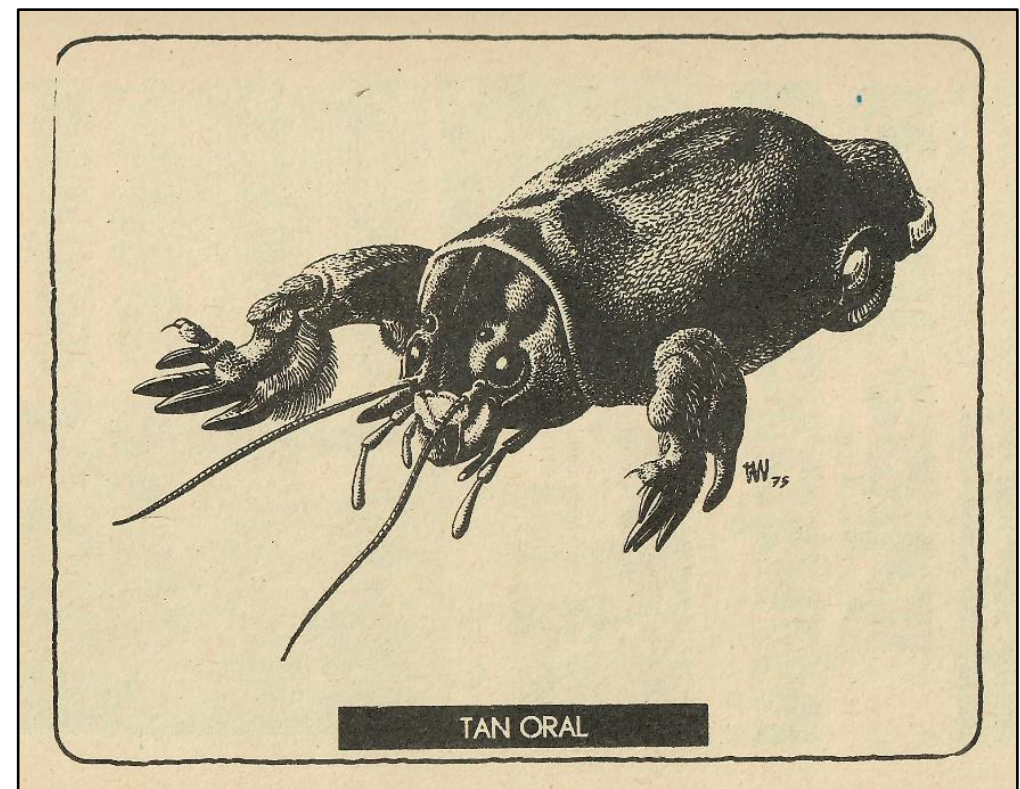

Görsel 8. Tan Oral'ın Politika dergisi için çizdiği bir karikatür dolmuşun nasıl algılandığına dair güçlü bir örnek sunuyor (s. 296)

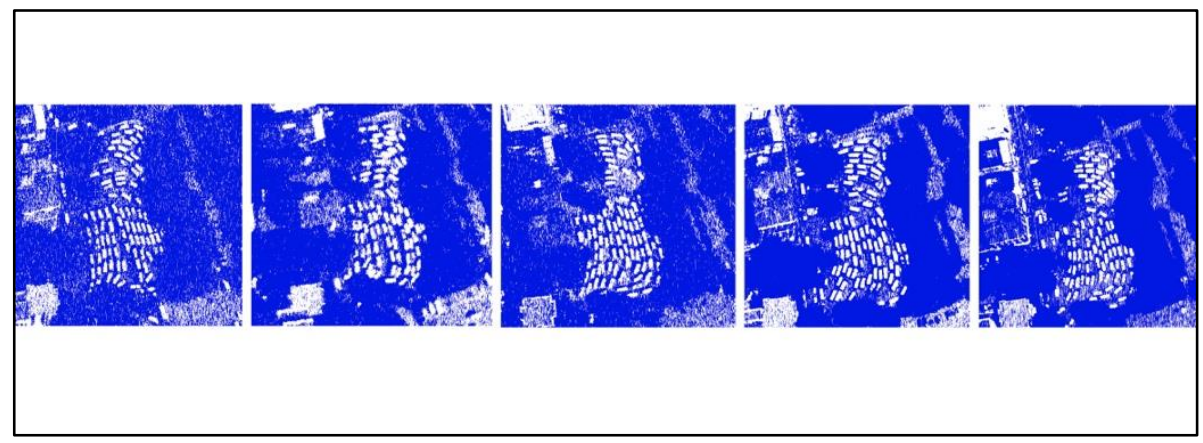

Görsel 9. Sezin Sarıca'nın “Mavi Labirent” isimli işi (2019) 


\title{
Extended Abstract
}

\section{The (Long) Story of Dolmuş/Jitney: Reading İlhan Tekeli and Tarık Okyay's Unprecedented Work on the Fortieth Anniversary of Its Publication}

\author{
$*$ \\ Besim Can Zirh \\ ORCID: 0000-0003-3506-6096
}

This essay was written to remind İlhan Tekeli and Tarık Okyay's work Dolmuşun Öyküsü (The Story of Dolmuş) published in 1980. This work was inspired by another research conducted by İlhan Tekeli and Tarık Okyay with Yiğit Gülöksüz in 1976. As they realized that the phenomenon of dolmuş was overlooked in newly developing body of research on urbanization in Turkey, Tekeli and Okyay decided to conduct a follow-up research with the students of Middle East Technical University, Urban Planning Department as their summer internship. This collective research was designed on mixed-methodology approached and aims to critically analyze taken-for-granted assumptions about dolmuş as a particular system of intracity transportation. Even on its fortieth anniversary of publication, The Story of Dolmuş continues to be relevant in the context of contemporary urbanization in Turkey.

I think this work is significant for two basic reasons. Initially, Tekeli and Okyay realized an interesting gap in the emerging literature on the phenomenon of gecekondu (shanty-town) in Turkey. Although dolmuş, as a very particular form of transportation, was very critical to understand this phenomenon, it had been entirely ignored in the studies focusing on gecekondu. Tekeli and Okyay understood this ignorance as a methodological blindness emanating from the class status of those who conducting this series of researches on gecekondu. As members of middle-class, most of the researchers tend to problematize the phenomenon of gecekondu as a pathology of the urbanization process, since the phenomenon is external to their urban experience. However, dolmuş could have very central role in their life regardless which part of the city they were living in. This is not one of the issues deliberately discussed 
in the book, but it is very important note to understand how the researchers' positionality can influence the knowledge production processes.

Secondly, Tekeli and Okyay applied mixed-methodology approached to overcome this methodological blindness. On the one hand, they included a series of official reports issued by the local governments on the question of transportation in different cities such as Ankara, İstanbul, İzmir and Mersin. Based on this desk-research, Tekeli and Okyay built models for the emergence and development of dolmuş lines in different cities. These models are significant for Tekeli and Okyay in developing one of their main arguments explaining differences in the transformation of these lines in relation to particular urbanization morphologies. On the other hand, it is also interesting to note that Tekeli and Okyay made an extensive review of news and humor magazines to contextualize the phenomenon of dolmuş in the public life of the period, in which working with such popular human sources (cultural studies) was not common even if it existed. Finally, Tekeli and Okyay conducted three-legged field research collectively with a cohort of university students. First part of the research is based on 12-question survey and conduced with the people who regularly using dolmuş lines. They were able to complete 902 questionnaires on 17 different dolmuş lines selected according to certain criteria. Second part of the research is also based on these selected lines and with the dolmuş drivers but based on semi-structured interview including 56 questions. The last part of the research is based on interviews with key-informants such as chair-persons of the chambers and municipal experts.

The main arguments of this study is built on the basis of this research part by which Tekeli and Okyay focuses on some basic profiling questions such as (a) who are these dolmuş drivers (occupational and educational background, family networks, capital ownership, working routines etc.), (b) who are their customers (occupational and educational background, gender, usages routines etc.), and (c) much more interestingly forms of interaction among these two groups by focusing on some issues such as bowing acquaintance and trust. I think these aspects of their research has certain resemblance to symbolic interactionalist approach which was not common to the generation of urban research in this period. One of the most critical findings of this research is about how the dolmuş drivers were organized in the forms of local chambers and how they could mobilize as an interest groups influencing public policy making processes related to transportation.

As a conclusion, in their wholistic effort, Tekeli and Okyay were successful to unfold taken-for-granted assumptions about the phenomenon of dolmuş. 
One of the strongest of these assumptions explains the phenomenon as something abnormal to the urbanization process thus it is going to be temporal. As a response to this assumption, Tekeli and Okyay indicated the fact that dolmuş lines develop in accordance with how urbanization process taking a particular path in different cities. In this sense, the phenomenon of dolmuş is not contradictory but complementary to these processes of urbanization in Turkey. Secondly, Tekeli and Okyay attempted to discuss the question of temporality as well. According to their understanding, the future of dolmuş is based on three determinants: (a) changes in the global economy (the role of fossil fuel as the main source of energy) and technological advancements in the field of inner-city transportation, (b) changes in national economic system and forms of political governance (how decisions are going to be made related to transportation policies) and (c) the organization of dolmuş drivers as an interest group. In the fortieth year of its publication, I think this book, Dolmuşun Öyküsü, would be still horizon broadening and inspirational for people working on urban issues from different disciplinary domains.

\section{Kaynakça/References}

Tekeli, İ., ve Okyay, T. (1980). Dolmuşun öyküsü. Ankara: Çevre ve Mimarlık Bilimleri Derneği.

Tekeli, İ., Gülöksüz, Y. ve Okyay, T. (1976). Gecekondulu, dolmuşlu, işportalı şehir. İstanbul: Cem Yayınevi.

Sarıca, S., (2019, 5 Ocak). Alternatif Mekân Deneyimleri 01: Mavi Labirent, Ankara. Zitlar Mecmuast. http://zitlarmecmuasi.com/alternatif-mekan-deneyimleri-01mavi-labirent-ankara/ 